\title{
DIE KULTURELE ROL VAN FRANKRYK IN AFRIKA
}

„Die kulturele rol van Frankryk in Afrika" was die onderwerp van die feesrede wat mnr. Joseph le Grand, algemene afgevaardigde van die Alliance française in Suid-Afrika, gehou het ter geleentheid van die viering van die tiende bestaansjaar van die Cercle français de Potchefstroom.

\section{Instrument}

„Om met sukses 'n kulturele rol te kan speel moet 'n land oor 'n doeltreffende instrument beskik. Die instrument is in die spesiale geval van Frankryk die Franse taal", het mnr. Le Grand gesê. Frans het die rol van Latyn as draer van die vroegste Europese kultuur oorgeneem. Maar dit het lank geduur voor die taal van die Franse uiteindelik sy beslag gekry het. Dit het gebeur in die sestiende eeu toe grammatici begin het om die taal te kodifiseer. Onmiddellik daarop bereik die taal van Frankryk, en daarmee gepaard gaande, sy kultuur, 'n eerste hoogtepunt in die sewentiende eeu, die eeu van die groot konings en in die agttiende eeu neem die verspreiding van Frans oor Europa 'n aanvang. In die volgende eeu swerm dié taal ook uit na die Noordelike en Ekwatoriale Afrika. Die kulturele rol wat Frankryk in hierdie gebiede gaan speel, loop oor twee tydvakke:

1. die voor 1950 en

2. die na 1950.

\section{Kolonialisme}

Die tyd voor 1950 is die van die kolonialisme. Die beleid van Frankryk was om 'n kulturele elite in Afrika te vorm. Die middel daartoe was die Franse onderwyskolleges, die Ecoles normales. Maar 'n elite bly steeds 'n beperkte groep, sodat in die koloniale tydvak slegs van 'n kulturele kern gepraat kan word. Die genoemde beleid is voortgesit tot om en by 1950. Afrika het toe in beweging gekom en 'n groot aantal lande het hulle van Frankryk losgemaak. 


\section{Lingua Franca}

Hierdie nuwe lande met hulle nuwe inheemse leiers het hulle wel losgemaak van Frankryk maar nie van die Franse kultuur nie. Daarvoor was lg. te "grandioos". Tog vind daar 'n belangrike verskuiwing van aksent plaas: die nadruk val nou nie meer op kultuur as sodanig nie. Sowel die ontvoogdes as die Franse self bevorder nou die ekspansie van Frans nie meer as 'n geskenk vir die "happy few" nie, maar as 'n praktiese verbindingsmiddel binne die lande self en ook daarbuite. Binnelands word meer eenheid verkry deur die gebruik van 'n algemene kommunikasiemedium en buitelands bind die Frans 'n hele aantal lande saam wat van mekaar geskei is deur die taalgrense van honderde taal- en dialekgroepe. Daar ontstaan iets wat die „frankofonie" genoem word. Dit is 'n binding van hoofsaaklik utilitêre aard tussen al diegene wat die Franse taal "gebruik". Frans word dus én die substansie én die dryfkrag van hierdie "frankofonie". Van taal van 'n beperkte kulturele elite in Afrika het Frans geword tot 'n kommunikasiemiddel met groot aksieradius en bygevolg ook tot draer van wat mnr. Le Grand noem: 'n nuwe humanisme.

\section{Boodskappe}

Dat hierdie frankofonie 'n werklikheid is het geblyk uit die talle boodskappe in Frans wat in die senaatsaal van die Potchefstroomse Universiteit voorgelees is deur die voorsitter van die Franse kring van Potchefstroom. Hierdie goeie wense het van so ver as New York in die Verenigde State gekom en hulle is bekroon deur 'n persoonlike brief van die ambassadeur wat deur sy plaasvervanger mnr. Pierre Justinard, konsel-generaal van Frankryk voorgelees is. Die ander lede van die buro van die Akademiese sitting was dr. Ludi Schulze wat voorgegaan het in die gebed, Madame Drogoul, kulturele attaché en prof. dr. W. N. Coetzee, dekaan van die fakulteit Lettere en Wysbegeerte, wat die Universiteit verteenwoordig het.

\section{Boeke}

Op die middaguur van dieselfde 7 September is 'n tentoonstelling van Franse luukse-boeke geopen in die kunslokaal van die Frans du Toit-gebou. Spreker was prof. dr. G. Dekker, 
stigter van die departement Frans en voorsitter van die Publikasieraad. Aansluitende by die woorde van mnr. Le Grand het prof. Dekker in Frans gewys op die taak van Frankryk en Suid-Afrika in Afrika, nl. om saam 'n nuwe en gelukkige Afrika te skep.

\section{Feesmaal}

Die leiding van die verdere verrigtings by die feesdis is waargeneem deur dr. M. J. H. du Plessis, sekretaris van die Franse Kring. Heildronke is ingestel op die Cercle français deur prof. dr. H. J. J. Bingle, rektor van die Universiteit en op die Staatspresident van Suid-Afrika deur die Franse konsulgeneraal. Mej. Elizabeth Heyns van die konservatorium wat in Parys gestudeer het, het Franse liedere gesing en die gesellige maaltyd is afgesluit met die Franse volkslied, die Marseillaise.

\section{Toekoms}

Die aanwesigheid van Franse kulturele en industriële leiers in Potchefstroom het historiese betekenis gekry omdat genoemde feesvierings plaasgevind het die dag nadat 'n belangrike buitelandse koloniale moondheid Afrika vir altoos verlaat het. Frans-Suid-Afrikaanse samewerking het gebiedend vir die toekoms geword en die handdruk van die voorsitter van die FransSuid-Afrikaanse Ontwikkelingskorporasie het simbolies vir Frans-Afrikaanse vriendskap en samewerking geword.

Die Franse het daarin geslaag om, na beëindiging van kolonialisme, hulle „présence” in Noordelike Afrika te behou. Hulle merkwaardige beleid kan dalk met groot nut deur ons, Afrikaners, die „leiers” in die Suide, bestudeer word.

Dit geld ook die rol van Afrikaans in die toekoms.

A. A. F. Teurlinckx. 